\section{Discovery of Chloroform Anæsthesia}

THE discovery of the use of chloroform as an anæsthetic, made by Sir James Young Simpson in Edinburgh in 1847, was marked by a graduation ceremony at the University at which the honorary degree of LL.D. was conferred on Dr. H. W. Featherstone, founder-president of the Association of Anæsthetists of Great Britain, and Mr. T. B. Simpson, a grand-nephew of Simpson. A meeting to discuss the present-day use of chloroform was also held, at which Prof. R. R. Macintosh (Oxford) and Drs. D. S. Middleton and John Gilles (Edinburgh) read papers. Dr. Douglas Guthrie, lecturer on the history of medicine in the University of Edinburgh, gave an address at a reception in the Upper Library, where an exhibition of Simpson relics had beon arranged. Dr. Guthrie said that the discovery of chloroform anæesthesia was one of the most dramatic episodes in the history of medicine, and with antiseptics had revolutionized surgery; it was remarkable that it had been delayed until the middle of last century. After graduating M.D. at Edinburgh in 1832, Simpson became assistant to Prof. John Thomson, professor of pathology, who advised him to specialize in midwifery. He was appointed professor of midwifery in the University in 1840, a post which he held until his death at the early age of fifty-nine in 1870. Since the discovery by Simpson of the anæsthetic properties of chloroform, there have been great advances in the technique of its administration, to which he himself contributed; and in spite of the introduction of many new substances, it still holds its place as a general anæsthetic.

\section{Carl Friedländer (1847-87)}

FRIEDLÄNDER's name is familiar to every medical student through 'Friedländer's bacillus', which he described in 1882. A capsulated micrococcus, this is not now considered pathogenic for true lobar pnoumonia, though it may cause the accompanying septicæmia. A native of Brieg in Silesia, Carl Friedländer was born a century ago on November $19,1847$. After taking the M.D. at the University of Berlin, he became assistant to Friedrich von Recklinghausen at Strassburg in 1874, and five years later was appointed to the modest post of assistant superintendent of post-mortem examinations in the Friedrichshain Hospital, Berlin. The courtesy title of professor was conferred on him only a few months before his death. Founder-editor of the Fortschritte der Medicin, Friedländer brought that journal to the front rank of German scientific periodicals. Among his most original work may be mentioned his description of thromboangiitis obliterans and his recognition of the tuberculous nature of lupus. He himself was a victim of pulmonary tuberculosis, which first manifested itself about 1882. His "Mikroskopische Technik" was a manual valued by student and expert alike.

\section{Dr. Charles Creighton (1847-1927)}

FOUNDER of modern British epidemiology, Charles Creighton, who was born on November 21, 1847, towered above his fellows yet partook of their foibles and frailties. After obtaining the M.D. at Aberdeen in 1878 and studying in Berlin and Vienna, he practised for a time in London, but his heart was nover in his work. He practically lived in the British Museum, where he collected material for his "History of Epidemics in Britain" (1891-94), described by
Garrison as a "classic of unimpeachable accuracy". To the gigantic task of translating unaided Hirsch's "Handbuch der historisch-geographischen Pathologie" for the New Sydenham Society he devoted twelve hours a day for three years. He was the most learned British medical scholar of the nineteenth century, who stood for something fundamental in the intellectual world of his generation. He was handicapped, however, by a curious mental obliquity which forced him to believe that the generally accepted must be necessarily false. Incapable of sharing much of the current medical teaching and frequently clashing with his medical colleagues, he brought matters to a head when in his article on vaccination in the "Encyclopædia Britannica" he declared that cowpox had nothing to do with smallpox, affording no protection against it. This was acclaimed by the antivaccinators, and Creighton was ostracized by the medical profession. He spent his last years in philosophical isolation in a tumble-down cottage at Upper Boddington, turning to Shakespeare for solace. His slender means were amplified by a Civil List pension secured for him by Mr. Asquith, who admired his learning.

\section{Hop Research in Britain}

A NEW research centre has been set up for hop production problems. It is situated at Wye College, Kent, and is to be administered by the College. The Ministry of Agriculture, the Hops Marketing Board and the Institute of Brewing will provide grants to meet the costs of maintenance, and the two last. named will bear the capital costs of establishing the centre. Scientific advice on the programme of work of the new centre and the staff necessary to carry out that programme will be given by the Agricultural Research Council; to assist on technical matters, the Council has a Committee on Hop Research, on which there are members nominated by the grantmaking bodies. The investigations at the new centre will include those concerned with soils, cultivation, varieties, breeding, diseases, brewing qualitios and storage, and there will be close co-operation with investigations on hop diseases carried out at the East Malling Research Station or elsewhere.

\section{Atomic Energy Train Exhibition}

THE atomic energy exhibition, organised by the Atomic Scientists' Association, was launched on November 6 at Liverpool by Sir James Chadwick. Speaking of the purpose of the exhibition, Sir James remarked that the excursion of scientific workers from the lecture room and the laboratory into the hurly-burly of public life was forced upon them by the urgency of the situation. Sooner or later the countries of the world will have to come to a decision about atomic energy, the trend of its development and the use to which it is to be put. This decision will have an important effect on the relations between nations and on the establishment of goodwill and confidence between them. In order to come to a wise decision it is necessary that the people at large should understand the fundamental facts. It is one of the aims of the Atomic Scientists' Association to explain to the public the facts about atomic energy. The main feature of the exhibition is the inclusion of experiments of the same type that are used in the laboratory. The first of the two coaches deals with the fundamental facts about atomic energy, and in it several Geiger counters are employed in order to demonstrate radioactive phenomena. The production 
of artificial radioactivity in silver by bombardment with slow neutrons is also demonstrated. The second coach deals with the practical applications of atomic energy, and it starts with a demonstration of the detection of fission in uranium. The gas diffusion, thermal diffusion and electromagnetic methods of isotope separation are all demonstrated on working models. The application of radioactive elements to medicine is illustrated on a film. All experiments are arranged to run automatically, but a member of the Atomic Scientists' Association is in attendance to give additional explanations.

The exhibition was first open to the public in Chester on November 10 . It went from there to Stoke, and its further itinerary includes Manchester, Blackpool, Carlisle, Glasgow, Dundee, Aberdeen, Edinburgh, Newcastle, Middlesbrough, York, Leeds, Sheffield, Derby, Coventry, Nottingham, Leicester, Birmingham, Shrewsbury, Swansea, Bristol, Cardiff, Oxford, Reading and London. Efforts are being made to extend the duration of the exhibition to enable it to visit more places in the south of England. Inquiries about the exhibition should be addressed to Dr. J. Rotblat, Physics Department, University of Liverpool.

\section{Starch Hydrolysis by Polarized Light}

IT has earlier been reported that exposure to polarized light induces hydrolysis of starch both in vitro and in the mesophyll of leaves. Now Dr. Elizabeth S. Semmens (Plant Physiology, 22, 270 278 ; 1947) describes experiments on the effect of polarized light on the starch content of stomatal guard cells. With a variety of plants and using both detached strips of epidermis and whole leaves attached to the parent plants, polarized light induces starch hydrolysis in the guard cells of the stomata; and this hydrolysis is accompanied by stomatal opening. Although in some cases the periods of exposure that preceded the observations were somewhat prolonged, these effects were also found when the period of exposure was only a few hours. With polarized direct sunlight the starch hydrolysis proceeded more vigorously, and bursting of the guard cells sometimes occurred. Although it appears likely that these observations, regarded as preliminary by the author, may, when extended, make a contribution to our knowledge of the vexed problem of stomatal mechanisms, their precise significance is at present difficult to assess.

\section{Dominion Observatory, Wellington}

THe annual report for the year 1944 of the Dominion Observatory, Wellington, N.Z., shows that there was a general decline in seismic activity as compared with previous years. There was some concentration of activity south of Lake Taupo, but the intensity anywhere did not exceed V + on the modified Mercalli scale and the shocks were not destructive. Sixty-one tremors were felt in the North Island, forty in the South Island and six in both. The Jaggar seismograph at Hastings was in operation again by July and the seismographs at Auckland, Arapuni, Tuai, New Plymouth, Bunnythorpe, Wellington, Takaka, Kaimata, Christchurch and Monowai were recording throughout the year. The death occurred on May 24, 1944, of Mr. A. W. Burrell of Stratford, who for some time operated a Jaggar seismograph for the Department of Scientific and Industrial Research in the Dominion.

\section{National Museums of Ceylon}

THIs Director's report for 1945 (published 1946) on the national museums of Ceylon includes the Colombo, Kandy, Ratnapura, Jaffna and Navala Museums. All have suffered, in varying degrees, the difficulties associated with requisition, evacuation, or other wartime contingency, and in some cases results have been serious. The present report, however, shows that these institutions are now returning to their normal peace-time activities. From the Colombo Museum, for example, it is reported that the important work on the Museum's collections in relation to Ceylon's extinct mammals, living fauna, prehistory and certain antiquities, was resumed and the results published during the year. Damage and losses are still being assessed in this Museum, and the Jaffna Museum reports that only a very small part of the Twynam collections (stored in the Old Dutch Church) will be fit for exhibition again. Lists of acquisitions in respect of each museum are given in detail.

\section{Anthropological and Archæological Work in India}

THE Journal of the Indian Anthropological Institute, vol. 1 (New Series), 1945, contains a number of interesting articles. Desiccation of Asia and its effect on human occupation is discussed by the late Sir Aurel Stein. Colonel Gordon surveys ancient Gandhara, and also describes some rock engravings and microliths in the Bangalore area. Colonel Gordon has long ago shown that most of the rock-shelter paintings and the rock carvings in India cannot be of any considerable antiquity. Nevertheless, such finds are of great interest, even if not very ancient. There are also papers on megalithic monuments of southern India by A. Aiyappan, and on Gond exogamy by M. P. Buradkar.

\section{French Scientific Library in London}

A small French scientific library is being built up at the Institut Francais du Royaume-Uni, London. Both books and periodicals can be borrowed by post. In addition, microfilms of articles appearing in periodicals not available in the library can be obtained. from France. These can either be consulted in the library, where a microfilm reader has been installed, or borrowed by post. All the library services are provided free. A catalogue of the books and periodicals available can be obtained from the Librarian, Scientific Library, Institut Français du Royaume-Uni, Queensberry Place, South Kensington, London, S.W.7.

\section{Institution of Civil Engineers : Council for 1947-48}

THE Council for 1947-48 of the Institution of Civil Engineers is as follows: President: Sir Roger Hetherington; Vice-Presidents : Sir Reginald Stradling, Sir Jonathan Davidson, W. H. Morgan, V. A. M. Robertson; Other Members of Council : H. E. Aldington, Sir Stanley Angwin, Prof. J. F. Baker, G. Baxter, D. B. Brow (India), W. S. Cameron, F. M. Corkill (New Zealand), H. F. Cronin, Sir Arthur Dean (India), Dr. W. H. Glanville, A. Gray (Canada), Dr. E. J. Hamlin (South Africa), A. C. Hartley, G. H. Humphreys, Sir Claude Inglis, L. Leighton, H. J. B. Manzoni, M. S. Moore (Australia), Prof. A. J. S. Pippard, A. S. Quartermaine, J. C. L. Train, W. K. Wallace, Sir Arthur Whitaker; Past-Presidents : Dr. D. Anderson, F. E. Wentworth-Sheilds, Sir Peirson Frank, Sir William Halcrow ; Secretary: E. Graham Clark. 